\title{
Romanos IV Diogenes' Attitude towards his Troops
}

\author{
Romanos IV Diogenes'in Birliklerine Karşı Tutumu
}

\begin{abstract}
Antonios VRATIMOS *
Abstract: Romanos IV Diogenes is well known for the battle of Mantzikert (August 1071 A.D.), the stronghold lying to the north of Lake Van on the Armenian plateau, given that this was the first time in Byzantine history an emperor was captured alive by the Seljuks. His responsibility for his army's crushing defeat has not received the attention that it deserves in modern scholarship. This article examines his attitude to his soldiers and officers; and further discusses whether it was in line with the prescriptions found in Byzantine military manuals. The Historia of Michael Attaleiates, a direct participant in all three of Diogenes' military campaigns in Asia Minor against the Turks, constitutes the main source for this research. Important information is also found in later chronicles that were written by Theodoros Skoutariotes, Constantine Manasses, George - the Monk - Hamartolos, and Zonaras. These chronicles remain little studied and some of them are still un-translated into modern languages. The article concludes that the emperor's own attitude had a quite negative impact on the morale of his soldiers, and caused the battle to be lost for the Byzantines before it was even fought.
\end{abstract}

Keywords: Romanos Diogenes, Alp Arslan, Battle of Mantzikert, Zonaras, Manasses, George -The Monk- Hamartolos, Skoutariotes

Öz: Romanos Diogenes IV, Bizans tarihinde ilk defa Selçuklular tarafından canlı olarak ele geçirilen bir imparator olarak, Ağustos 1071'de Malazgirt (Ermenistan platosundaki Van Gölü'nün kuzeyindeki ana yer) savaşı ile oldukça iyi tanınmaktadır. Ordunun ciddi yenilgisindeki sorumluluğu şimdiye kadar modern araştırmacılardan hak ettiği değeri bulamamıştır. Bu çalışma, askerlerine ve memurlarına yönelik tutumunu incelemekte ve bunun ötesinde Doğu Roma askeri el kitaplarındaki yönergelere uygun olup olmadığını tartışmaktadır. Diogenes'in Türklere karşı yaptığı üç Anadolu kampanyasına da doğrudan katılan Michael Attaleiates'in Historia kitabı, bu konunun ilk kaynağını oluşturmaktadır. Bununla birlikte, önemli bilgiler daha sonra Theodoros Skoutariotes, Constantine Manasses, keşiş George Hamartolos ve Zonaras tarafından yazılan kroniklerde de bulunmaktadır. Bu kronikler çok az çalışılmış ve bazıları hala modern dillerde çevrilmemiştir. Çalışma, imparatorun askerlerine davranışının, onların moralini oldukça olumsuz yönde etkilediğini ve savaşmadan önce Doğu Romalıların savaşı kaybetmelerine neden olduğu sonucuna varmıştır.

Anahtar sözcükler: Romanos Diogenes, Alp Arslan, Malazgirt Savaşı, Zonaras, Manasses, Keşiş George Harmatolos, Theodoros Skoutariotes

In 1068 Romanos Diogenes - a soldier by profession - was selected as emperor to replace the dead Constantine Doukas. His first two military campaigns against the Seljuks met with some success, but nothing decisive. In 1071 he led his third and last campaign to recover possession of the fortresses to the north of Lake Van, which were now held by the Turks. Alp Arslan was somewhere in Syria when he was told about Diogenes' advance towards the Anatolian border. He immediately marched to the scene with a force numerically inferior to that of Diogenes. At Theodosioupolis (Erzurum), the emperor sent off the Franks of the Latin chieftain, Roussel de

\footnotetext{
* Assist. Prof. Dr., University of Sakarya, Faculty of Arts and Sciences, Department of History, Esentepe, Sakarya. vratimos@sakarya.edu.tr, https://orcid.org/0000-0002-5908-4494
} 
Bailleul, and the Scythians to Chliat (Akhlat). Later, a second detachment under the command of Tarchaneiotes was also ordered to march to the assistance of the forces at Chliat. Diogenes, after reducing Mantzikert (Malazgirt), moved to join them. It was at this time that the foraging parties of his army were harassed by a group of Seljuks. The emperor recalled the Franks with the magister Tarchaneiotes, but they did not obey. He then decided on battle, giving the signal for the attack. The Byzantines, who were tricked by the feigned retreat of the enemy, suffered a sound defeat, while the emperor himself was taken captive. The battle of Mantzikert is a key event in both Byzantine and Turkish history. This was the beginning of the end for Byzantium given that it gradually changed the balance of power in Anatolia and the Mediterranean.

In his monumental book, titled: "The Decline of Medieval Hellenism in Asia Minor and the Process of Islamization from the Eleventh through the Fifteenth Century", Speros Vryonis jr. $(1971,103)$ lists as reasons for the crushing defeat of the Byzantines at Mantzikert in 1071: a) the unceasing strife between the landed military nobility and the bureaucratic aristocracy of Constantinople; b) the desertion of the Uzes and the Frankish mercenaries on the news of Alp Arslan's presence nearby; c) the attack of the Germans (Nemitzoi) on Diogenes during his last campaign; d) the perpetual tensions between the Byzantines and the Armenians; c) the overall decline of the imperial army in the second half of the eleventh century; and e) the treachery of Andronikos Doukas who withdrew with the rearguard in the thick of the battle. Later opinions dispute some of them, like the Armeno-Byzantine discords (e.g. Dédéyan 1975, 115; Cheynet 1990, 401, n. 113; Cheynet 1996, 70-71; Garsoïan 1998, 82), or the betrayal of Tarchaneiotes and Roussel, as they both ignored the call for help before the battle began (e.g. Shepard 1975, 222; Leveniotis 2004, 95-99; Beihammer 2017, 156). Romanos Diogenes' own responsibility concerning the defeat of his army has not been systematically examined to date.

The idea for this paper originates from research conducted on secondary Greek sources. There are two principal reasons why they have been chosen to be featured here, and have been analysed by two renowned scholars in the field of Byzantine literature: A) the more distanced the author is from the events he records, the more impartial and thus reliable his work must be (Macrides 1996, 207); and B) the repetition of older sources should not be treated as a sign of plagiarism, but as a proof of the accuracy and reliability of the material (Nilsson 2006, 51-52). Attaleiates, who witnessed all three of Diogenes' military campaigns in Asia Minor, has been charged with subjectivity in his account from the emperor's rise to power (1068) to the second year of Nikephoros III Botaneiates' reign (1079-80), where the book ends (Ostrogorsky 1969, 317). On the other hand, the chroniclers not only make things come "true" with their scissorsand-paste technique, but also contribute valuable addenda to their source texts. Furthermore, it is not uncommon that in a later chronicle a lost (perhaps contemporary) text has been utilised. This is the case of the Historia Imperatorum that derives from a Byzantine text now lost to us, as Sakel $(2009,245 ; 2017,148)$ postulates. In general terms, chroniclers provide shortened, or abbreviated, versions of previous texts, including or excluding material according to their own taste. That they dedicate space in their works to informing about the emperor's behaviour, and also link it with the plot of the Doukai, is of considerable importance; hence it requires further examination. The present study aims to illustrate Diogenes' character traits, as those appear in those chronicles, focusing upon their effects on his imperial army. It concludes that his severe and cruel attitude lowered further the soldiers' already low morale, breaking too their fighting spirit.

The chronicles discussed below do not include details of how the emperor handled each military circumstance, but briefly outline his character traits at the beginning or the end of the sections describing his reign. I shall take as my point of departure the thirteenth-century work, Synopsis Chronike, whose authorship has been attributed to the bishop of Kyzikos, Theodoros 
Skoutariotes (Zafeiris 2011, 253-263). He depicts the emperor Diogenes as "cruel, miserable, fierce to everybody, and haughty, appearing hateful not only to the senate, but also to his own

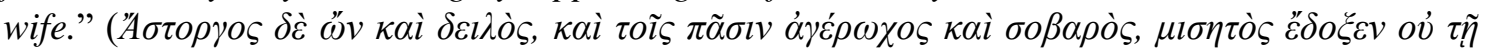

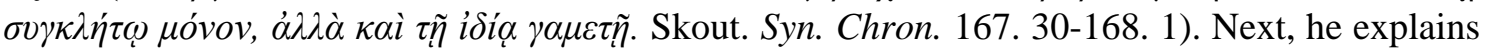
his criticism in saying: "For this, and in the course of his third campaign, he was captured by the Turks during the battle. And after he was released, he did not refrain from again claiming

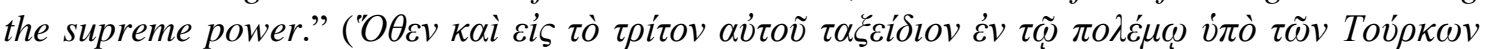

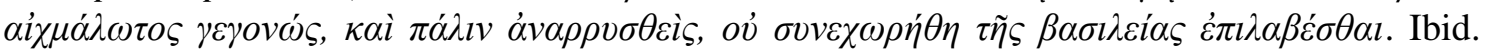
168. 1-4). He goes further to say that Diogenes' character was why his spouse issued a decree, ordering all cities not to offer him shelter (ibid. 168. 4-7. Her role in the despatch of this order is discussed by Vratimos 2013, 277-284).

Likewise, the Continuator of George (the Monk) Hamartolos describes Diogenes, in the Chronikon Breve, as a man who,

was arrogant by nature, self-satisfied, disdainful, also greatly unlikeable, and haughty. But he became much more arrogant since he assumed the supreme power. He was unstable in his opinion and suspected everyone either his own or foreign people (this may denote high-ranking officials, courtiers, or distant acquaintances), thinking that almost everyone is plotting against him. On this account, he was greatly tedious and fierce, and was alienated (literally: non-saluted) not only from his own magistrates, but from his spouse and his step-sons. On this account, they called meetings everywhere to decide how to trap him, for they detested him, and decided to surrender him to the Saracens (i.e. the Turks) before a battle. The caesar, Constantine Doukas' brother, drew up this [plan], and developed it with his son Andronikos who, then, commanded the Roman (i.e. the Byzantine) army, together with certain other generals and grandees; and they weaved for such a king, or better say against him, a net of deceit.

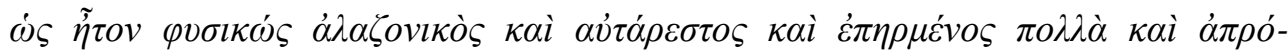

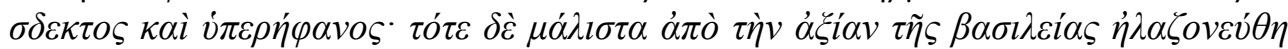

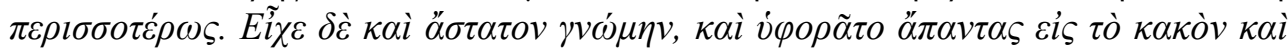

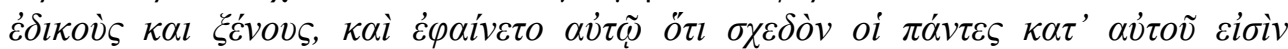

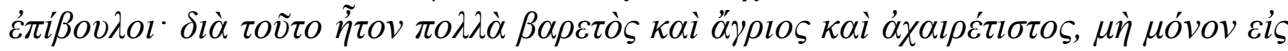

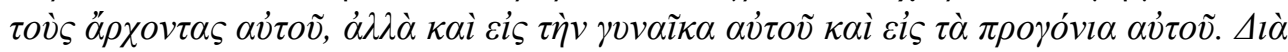

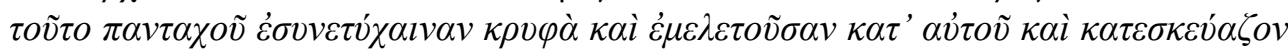

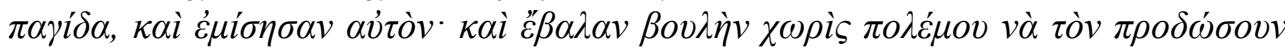

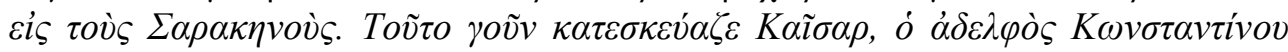

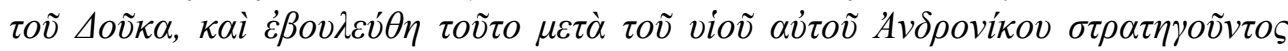

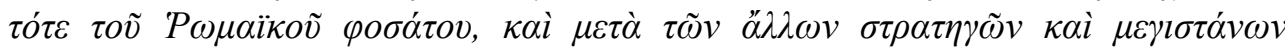

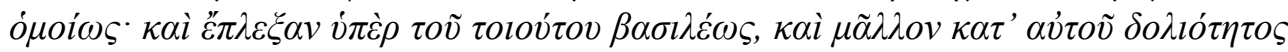
diktvov (Hamart. Chron. Breve, col. 1241).

Along the same lines is the Historia Imperatorum whose anonymous chronicler does not omit to also refer to the role of John Doukas as the ringleader of the plot against the emperor (since the complete text is unedited, I consulted the Berne manuscript: Bern, Burgerbibliothek, cod. 596, ff. 215r.17-215v.8, http://www.e-codices.unifr.ch/en/bbb/0596/215r/0/Sequence-40). It should be noted that no systematic research has been done on what the origins of those details in his source might have been. Many striking parallels, though, are detected between the two works (the Chronikon Breve and the Historia Imperatorum) and the Chronicle of Constantine Manasses who writes in political verse (on the genre, see Jeffreys 1974, 143-195, while on the 
use of the text in relation to its composition, see Nilsson \& Nyström 2009, 42-60). In the work of Manasses, Diogenes is portrayed as,

independent by nature, presumptuous,

supercilious, arrogant, and selfish who trusted his own judgement.

The purple robe puffed him up;

[but] his conceit grew even worse once he became Roman emperor;

and indeed, since he was unstable in his opinion

and [was behaving] in an erratic manner, distrusting everyone

and suspecting everyone - either close or distant ones -

as treacherous who kept watching his back,

he appeared tedious and harsh not only to the magistrates,

but even to his spouse and the sons of Doukas.

Thenceforth discussions, whisperings, treacheries and cunnings [began];

thenceforth odd hatred, nets, and traps [were being prepared];

and they planned to deliver the emperor to the enemy beforehand,

[as though he were] an easy, untroubled, and the readiest prey.

The man who mixed up this drink of treason

was the caesar, the brother of Constantine Doukas,

since his son was a general at that time.

Then, the plan was put forward to the generals and his son;

and a net of danger had being prepared for this miserable,

and a black garment was being weaved for [his] death.

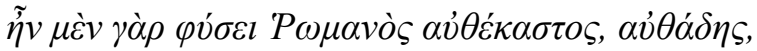

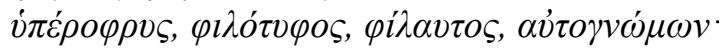

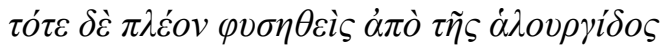

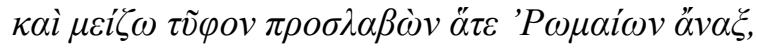

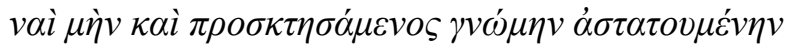

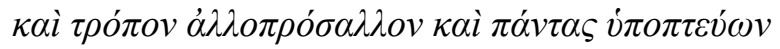

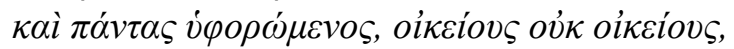

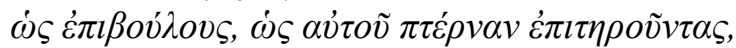

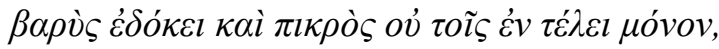

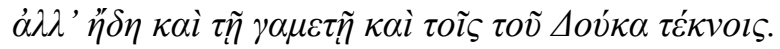

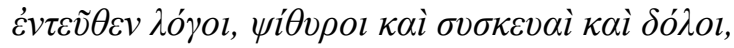

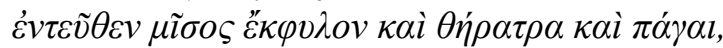

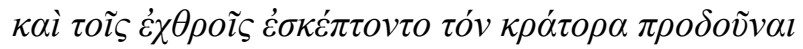

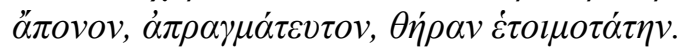

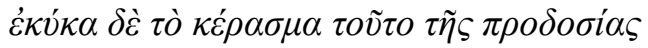

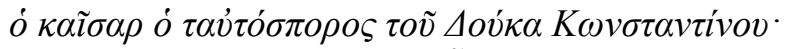

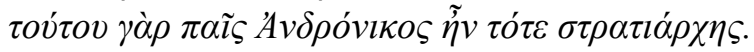

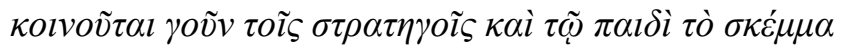

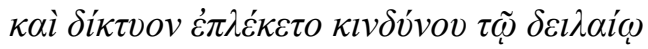

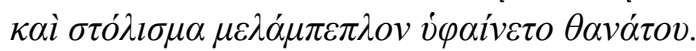

(Manas. Brev. Chron. 347. 6408-348. 6427).

In the Epitome Historion by the twelfth-century chronicler and canonist Zonaras, Diogenes is described as "arrogant and unsubdued", and as a man who "wished to keep the reins of power

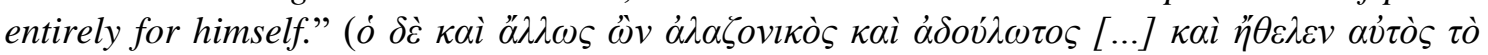
$\kappa \rho \dot{\tau} \tau o \varsigma \kappa \alpha \theta \alpha \rho \tilde{\omega} \varsigma \dot{\alpha} v \alpha \delta \dot{\eta} \sigma \alpha \sigma \theta \alpha$. Zonar. Ep. Hist. 688. 5-10). Contrary to what said earlier, John 
Zonaras [he is regarded as an objective historian (Hunger 1978, 417), handling his material in an independent way (Ostrogorsky 1969, 212)] states that the emperor's arrogance grew worse after his 1068 campaign, "as if he may have brought it to the most successful end." (Ibid. 692. 510). A similar declaration is found in the Chronographia of the eleventh-century statesman, philosopher and writer Michael Psellos: "his (i.e. the emperor's) manner was straightforward,

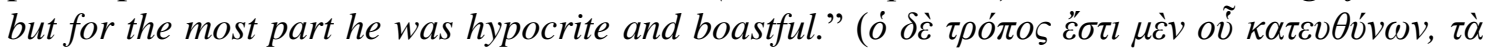

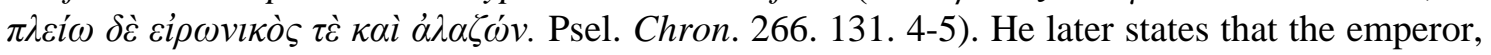
"wished to be an absolute sovereign, governing the affairs of the state entirely on his own." ( $\dot{ }$

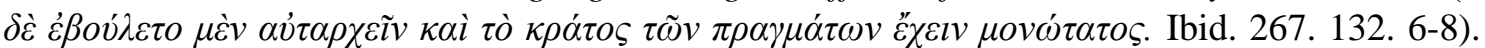
Zonaras is far more detailed than other chroniclers, recording, too, Diogenes' merciless order of executing the enemy captives during the 1069 campaign, and his fierce envy at the exploits of the general Komnenos in 1070 (Zonar. Ep. Hist. 692. 5-10; 694. 8-14). The first of those two occasions is vividly described by Attaleiates:

On the next day [Diogenes], making a public assembly, observed the captives of the enemy, and ordered that they be sentenced with death penalty, without sparing anybody, not even the man declaring his commanding brilliance - it was evident that he was the commander from his clothes, for he was splendid in them with the weapons and other equipment, although he offered to pay a considerable ransom for his freedom and also to exchange himself for a large number of Roman captives.

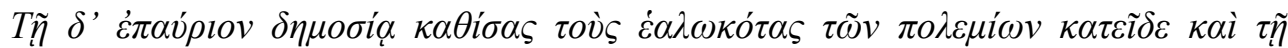

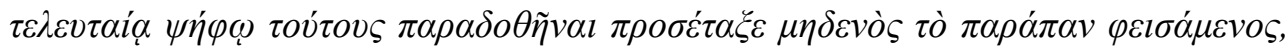

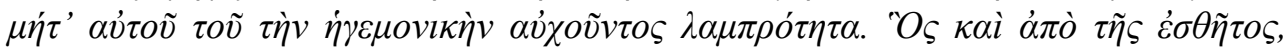

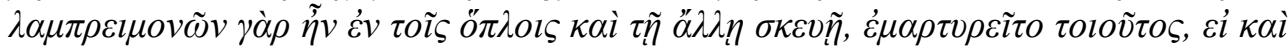

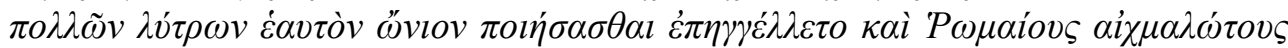

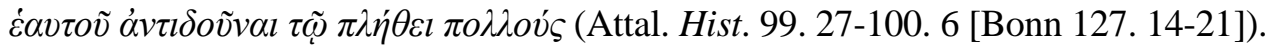

It is noted that the imperial and ecclesiastical authorities were spending a huge sum of gold to release slaves, hostages, or prisoners of war; and there exist numerous examples of such cases (e.g. Patoura 1994, 24, and n. 22; Koukoules 1949, 173-175). In the case under consideration, it may be of some importance to say here that though the Turkish leader offered both captives and ransom to free himself, Diogenes refused to accept, violating in this way the prescriptions of Byzantine military textbooks (Leo VI Taktika 384, par. 9. The same textbook also refers to the use of enemy captives for safe marches through hostile territories. Ibid. 172-174, par. 48). Undoubtedly his decision mirrors the unrelenting harshness of his character. Attaleiates states that the troops were reluctant to advance on command due to the lack of pay and emoluments (Vryonis 2003, 23-25; Haldon 2003, 58-59). In a council of war, the author had proposed that the army should march deeper into Anatolia, arguing that the collection of ransoms and spoils would raise the soldiers' morale (Attal. Hist. 102. 13-16 [Bonn 131. 1-4]). Yet, the emperor did not pay any attention to these words. It is reasonable to conjecture that his decision against the release of captives had negative effects on the army, mainly on the native soldiers, fearing that the same fate would befall them, if they were captured by the Turks.

As to Manuel Komnenos, we read in the Historia that Diogenes seemed to rejoice at the successes of his general. Yet, no one could say how he truly felt (Attal. Hist. 108. 20-22 [Bonn 139. 12-15]. See discussion in Tsolakis 1969, 195). Unlike Attaleiates, the Continuator of John Skylitzes, one of Zonaras' sources (Karagiannopoulos 1987, 321; Tsolakis 1964, 83), declares directly that a considerable part of the Byzantine army was sent off to Hierapolis (Manbij) due to the emperor's envy of Komnenos (Skyl. Cont. 139. 19-24). The military manuals, however, forbid feelings which might cause envy, recommending instead the emulation and imitation of 
generals successful in battle (Leo VI Taktika 630, par. 43). It is questionable what the reaction of other officers was upon the news that Komnenos' army was wiped out at Sebasteia (Sivas). It may not be a mere coincidence that Constantine Manasses and the anonymous chronicler of the Historia Imperatorum chronologically place the entrance of officers into the conspiracy of the Doukai just before Diogenes departed from the capital to meet his fate in the conflict with the sultan. The events of his doomed campaign in 1071 come next in our discussion.

In the Epitome Historion, there are three points that merit some attention. Zonaras states that Diogenes "advanced as far as in the theme of Anatolikon, but, contrary to custom, he was

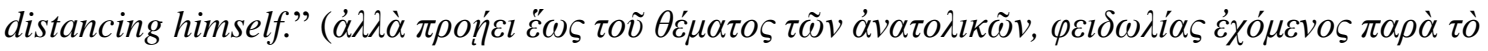

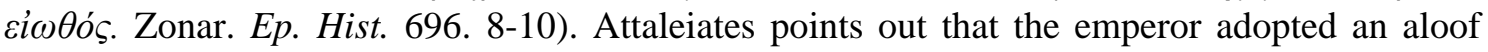

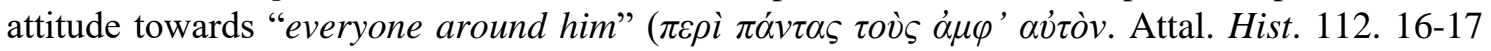
[Bonn 144. 20-21]); and further down we learn that, "several times, he was distancing himself from the army [to stay] in his own quarters, displaying his own properties and setting [issues

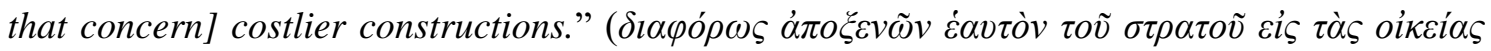

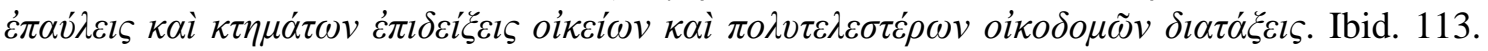
14-16 [Bonn 146. 2-4]). Diogenes' staying in his splendid properties, entirely isolated from the army camp, is another act against the recommendations of military textbooks which talk about frugality and simplicity of needs (Leo VI Taktika 16, par. 5). This provocative attitude could not maintain his men's morale and motivation. On the contrary, it apparently sparked negative feelings amongst them.

The next point is related to the unruly behaviour of the German mercenaries in the army which laid waste the land of local provincials. Their plundering and looting caused Diogenes' forceful reaction: "Here (i.e. at Krya Pege), he inflicted harder punishments for wrong doings

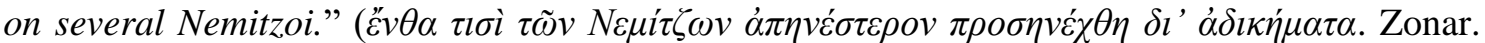

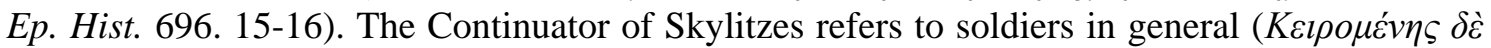

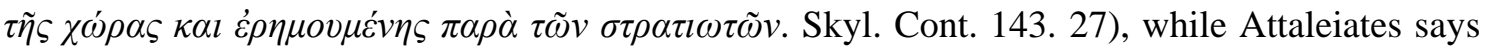
that this plundering was carried out, "by [indigenous] soldiers, but mostly by mercenaries and

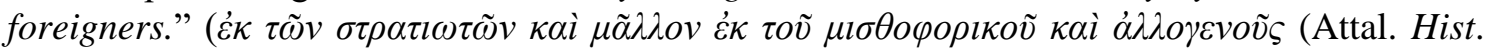
114. 1-2 [Bonn 146. 20-21]). The context, though, makes it evident that only the Nemitzoi were punished. The military manuals recommend that, "a soldier stealing anything whatever at any

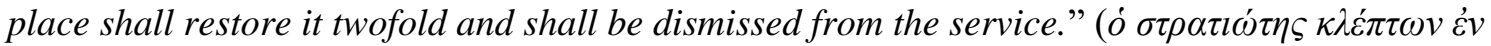

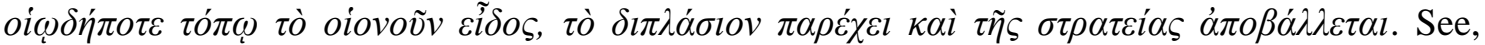
Ashburner 1926, 109). In our case, it is unknown what punishment was inflicted on them; but the usage in the text of the comparative form $\dot{\alpha} \pi \eta v \varepsilon \dot{\sigma} \sigma \varepsilon \rho \rho v$ (rougher or harsher) rather than the neuter $\dot{\alpha} \pi \eta v \varepsilon \dot{\varepsilon} \varsigma$ illustrates that their punishment was severe (Attal. Hist. 114. 3-4 [Bonn 146. 23]; Skyl. Cont. 143. 27-144. 1). This is not the sole occasion that Attaleiates is critical of Diogenes. After the surrender of Mantzikert, a soldier was punished for the theft of a mule. The emperor did not impose a fine on the convicted person. He ordered instead that his nose be cut off. For

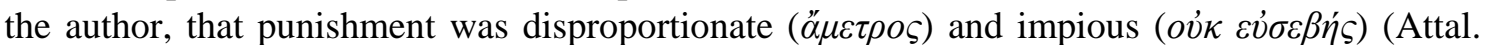
Hist. 118. 13-24 [Bonn 152. 21-153. 10]. Also, see discussion in Haldon 2002, 283). More than this, the sentence was executed publicly, although the Taktika of Leo VI (32-34, par. 28; 568570) warns that unjust punishments instil enmity and strike fear into soldiers.

The last point concerns the sultan's ambassadors who negotiated a peace treaty with the emperor before the battle at Mantzikert. By Zonaras' account, the latter "received them in no friendly way at all", talking to them "in an even more arrogant manner" (Zonar. Ep. Hist. 699. 14-15; 700. 4; Attal. Hist. 123. 10-12 [Bonn 159. 12-14]). This attitude to ambassadors is highly disapproved in military manuals (Leo VI Taktika 548, par. 33). That the emperor is portrayed as arrogant by nature has been mentioned earlier. The way he treated the ambassadors should not 
come as a surprise to us. Likewise, Psellos says that after the end of the first campaign the emperor, "utterly disregarded the magistrates, he was alienated from advisers [...], and used

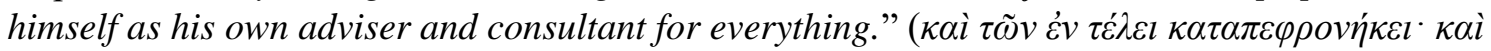

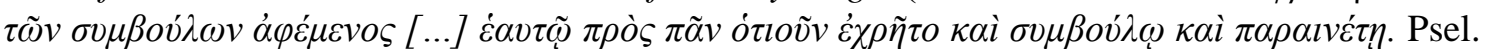
Chron. 268. 135. 2-4). Further down we read: "From then onwards, his boasting [grew] louder and his insolence [became] greater, because he directed two military expeditions. For this reason he [stopped] paying attention to others, while the wicked people he consulted, had

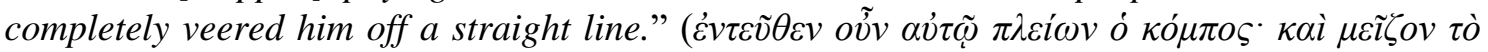

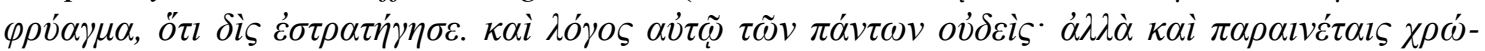

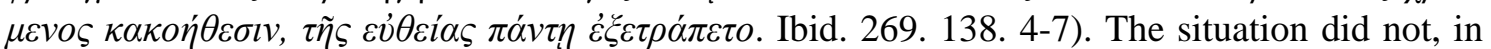
fact, change over time, for the emperor, as Psellos notes, continued, "to pay no heed to others'

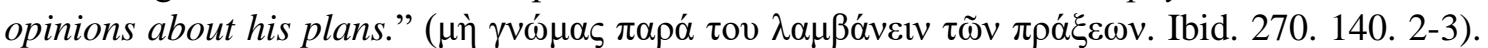
Though it is maintained that Psellos criticises Diogenes severely (Vryonis 1992, 128; Cheynet 1980, 418), Attaleiates seems to corroborate his close contemporary. In the section recounting the campaign of 1069 , he is telling us that the emperor, "remained in the camp for three days, apparently because he was satisfied with this victory (i.e. it was against a Turkish group in the

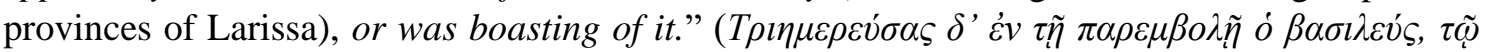

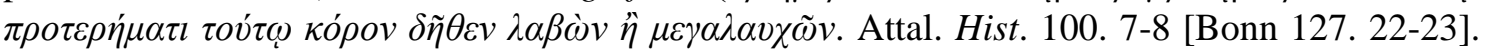
That Attaleiates made use of Psellos' Chronographia to articulate his own positions has been satisfactorily discussed by Krallis 2006, 167-191; 2012, 81-100). The emperor's arrogant and snobbish manner is further shown in his refusal to meet at the palace court Chrysoskoulos, the brother-in-law of Alp Arslan (Byen. Hyle. Hist. 101.5). Finally, their meeting took place after many days had gone by (Attal. Hist. 110. 21-23 [Bonn 142. 9-11]). The reason is unclear, but it most probably relates to Diogenes' feelings of envy towards Manuel Komnenos.

To conclude: the condition of the army when the emperor conducted his 1068 campaign is colourfully depicted by Attaleiates, explaining that the soldiers were unpaid and deprived of weapons (Attal. Hist. 81. 22-82. 15 [Bonn 103. 3-104. 3]). Their bad condition is directly linked to bad morale. According to Tsoungarakis $(2003,284)$, a) they were aware of their inability to face Turkish forces, and b) they had put personal interests above the common good. Diogenes sought to reverse this situation. He facilitated the recruitment of young soldiers, "encouraging them [with distribution of] dignities and gifts". In a very short time he managed to organise an

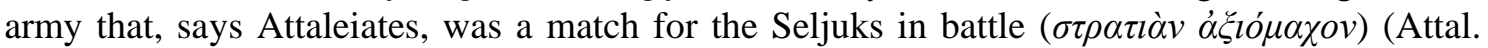
Hist. 82. 24-31 [Bonn 104. 13-19]). Did the measures make things better? The answer is rather negative. Two examples in the Historia illustrate the bad state of readiness of the army on the eve of the battle at Mantzikert. The first deals with Bryennios' failure to drive off a Turkish detachment that harassed the foragers scouring the countryside for supplies. Upon news of his defeat, the emperor "summoned an assembly and gave a public oration - contrary to custom -

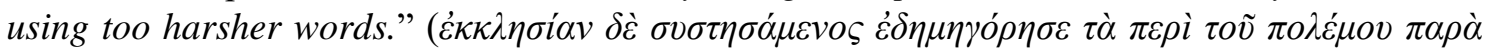

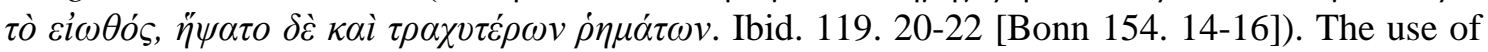
harsh and abusive language, as military manuals underline, does not inspire the men's courage or tenacity (Leo VI Taktika 20, par. 12; 626, par. 22). A remark on the emperor's unawareness of why Bryennios called on reinforcements is indicative of Attaleiates' disagreement with this attitude (Ibid. 119. 19-20 [Bonn 154. 13-14]). The second example manifests the psychological consequences for Byzantines to hear, during the night, the Seljuks gallop around the camp and shoot their arrows inside. Attaleiates gives a vivid picture of the situation: "everyone spent the night staying awake and having their eyes open; for who could fall asleep when the danger of

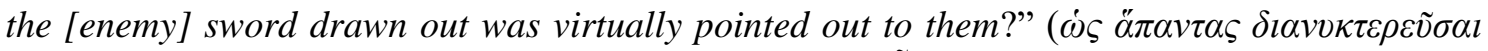

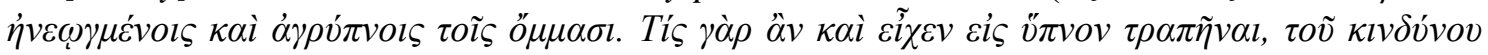

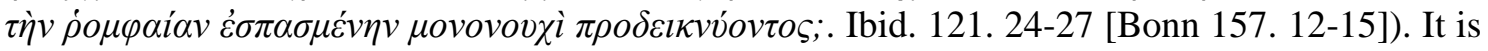


most probable that Diogenes was well aware of the terror that had overcome his men; hence he personally took part in the actual battle, although the military textbooks prescribe against it except if the men's morale is fragile (Leo VI Taktika 590, par. 153; 290, par. 3). Yet, there are no reports that he tried to boost their self-confidence. His aloof and severe behaviour made his generals turn from him, and his soldiers reluctant to fight wars, fearing for their own lives. On this basis, we can conclude that the sultan had already obtained the psychological advantage over the Byzantines who fought at Mantzikert. The consequences of going into battle with no sleep and enough rest are presented in Kekaumenos' Strategikon (Tsoungarakis 1996, 90-94), par. 27), the textbook which takes the form of admonishments to his son. As to whether or not Diogenes could have delayed or perhaps avoided the battle, it will form the subject of another study.

\section{REFERENCES}

\section{Ancient Sources}

Attal. Hist. (= Attaleiates, Historia) Text: Michaelis Attaliatae Historia. Ed. E. T. Tsolakis. Athens 2011 (Corpus Fontium Historiae Byzantinae 50). Text: Michaelis Attaliotae Historia. Eds. W. B. de Psesle \& I. Bekker. Bonn 1853 (Corpus Scriptorum Historiae Byzantinae).

Byen. Hyle.Hist. (= Bryennios, Hyle Historias). Text and translation: Nicéphore Bryennios Histoire. Ed. P. Gautier. Brussels 1975 (Corpus Fontium Historiae Byzantinae 9).

Hamart. Chron. Breve. (= Hamartolos, Chronicon Breve) Text: Georgius Monachus, Chronicon Breve. Ed. E. De Muralto. Paris 1863 (Patrologia Graeca 110).

Historia Imperatorum. URL: http://www.e-codices.unifr.ch/en/bbb/0596/215r/0/Sequence-40. Bern, Burgerbibliothek, cod. 596, ff. 215r.17-215v.8.

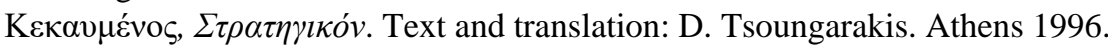

Leo VI Taktika. Text and translation: The Taktika of Leo VI. Ed. G. Dennis. Washington D.C. 2010 (Corpus Fontium Historiae Byzantinae 49).

Manas. Brev. Chron. (= Manasses, Breviarium chronicum) Constantini Manassis: Breviarium chronicum. Ed. O. Lampsides. Athens 1996 (Corpus Fontium Historiae Byzantinae 36/I-II).

Peri Stratiotikon Epitimion. W. Ashburner (1926). "The Byzantine Mutiny Act". Journal of Hellenic Studies 46 (1926) 80-109.

Psel. Chron. (= Psellos, Chronographia) Text: Michaelis Pselli Chronographia. Ed. D. R. Reinsch. Berlin - Boston 2014 (Millennium Studies 51/I-II).

Skout. Syn. Chron. (= Skoutariotes, Synopsis Chronike). Text: Anonymou Synopsis Chronike. Ed.: K. Sathas. Paris 1894 [repr. Athens 1972] (Mesaionike Bibliotheke 7).

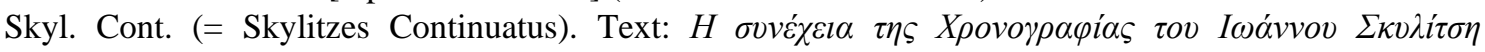
(Ioannes Skylitzes Continuatus). Ed. E. Th. Tsolakis. Thessaloniki 1968.

Zonar. Ep.Hist. (= Zonaras, Epitome Historion) Text: Ioannis Zonarae epitomae historiarum libri XIIIXVIII. Ed. T. Büttner-Wobst. Bonn 1841-1897 (Corpus Scriptorum Historiae Byzantinae I-III).

\section{Modern Literature}

Beihammer A. D. (2017). Byzantium and the Emergence of Muslim-Turkish Anatolia, ca.1040-1130. London - New York 2017.

Cheynet J.-C. (1980). "Mantzikert: une désastre militaire?". Byzantion 50 (1980) 410-438.

Cheynet J.-C. (1990). Pouvoir et contestations à Byzance (963-1210). Paris 1990 (Byzantina Sorbonensia 9).

Cheynet J.-C. (1996) "Les arméniens de l'empire en Orient de Constantin X à Alexis Comnène (10591081)". Eds. J.-C. Cheynet et al., L'Arménie et Byzance: histoire et culture. Paris (1996) 67-78.

Dédéyan G. (1975). "L'immigration arménienne en Cappadoce au XI siècle". Byzantion 45 (1975) 41-117.

Garsoïan N. G. (1998). "The Problem of Armenian Integration into the Byzantine Empire”. Eds. H. Arhweiler - A. Laiou, Studies on the Internal Diaspora of the Byzantine Empire. Washington D. C. (1998) 53-124.

Haldon J. (2002). "The Krites tou Stratopedou: A New Office for a New Situation?". Travaux et Mémoires 14 (2002) 279-286.

Haldon J. (2003). "Approaches to an Alternative Military History of the Period ca. 1025-1071". Ed. V. 
Vlyssidou, The Empire in Crisis(?) Byzantium in the $11^{\text {th }}$ Century (1025 -1081). Athens 2003 (45-74).

Hunger H. (1978). Die hochsprachliche profane Literatur der Byzantiner. Vol. I. Munich 1978.

Jeffreys M. (1974). "The Nature and Origins of the Political Verse". Dumbarton Oaks Papers 28 (1974) 143-195.

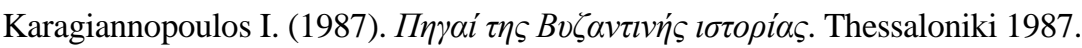

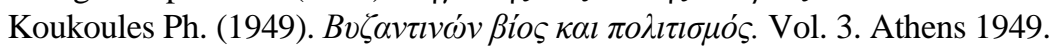

Krallis D. (2006). "Attaleiates as a Reader of Psellos". Eds. Ch. Barber \& D. Jenkins, Reading Michael Psellos. Leiden - Boston (2006) 167-191.

Krallis D. (2012). Michael Attaleiates and the Politics of Imperial Decline in the Eleventh-Century Byzantium. Tempe 2012 (Medieval and Renaissance Texts and Studies 42).

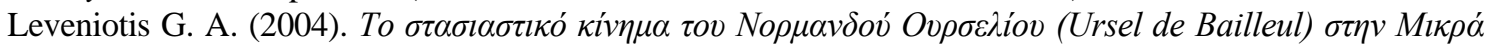
Aoía (1073-1076). Thessaloniki 2004.

Macrides R. (1996). "The Historian in the History". Ed. C. N. Constantinides et al., Fillelen, Studies in Honour of Robert Browning. Venice (1996) 205-224.

Nilsson I. \& Nyström E. (2009). "To Compose, Read, and Use a Byzantine Text: Aspects of the Chronicle of Constantine Manasses". Byzantine and Modern Greek Studies 33/1 (2009) 42-60.

Nilsson I. (2006). "To Narrate the Events of the Past: on Byzantine Historians, and Historians on Byzantium". Ed. J. Burke et al., Byzantine Narrative: Papers in Honour of Roger Scott. Leiden Boston (Byzantina Australiensia 16) (2006) 47-58.

Ostrogorsky G. (1969). History of the Byzantine State. Trans. J. Hussey. New Brunswick - New Jersey 1969.

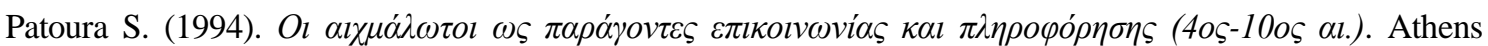
1994.

Sakel D. (2009). "Anonymi Historia Imperatorum, parte prima. Introduzione, testo critico, versione italiana italiana, note e indici a cura di Francesca Iadevaia. Messina 2000”. Byzantinische Zeitschrift 102/1 (2009) 242-245.

Sakel D. (2017). “Again on the Historia Imperatorum - and on the Mantzikert Campaign”. Byzantinische Zeitschrift 110/1 (2017) 141-148.

Shepard J. (1975). "Byzantinorussica”. Revue des études byzantines 33 (1975) 211-225.

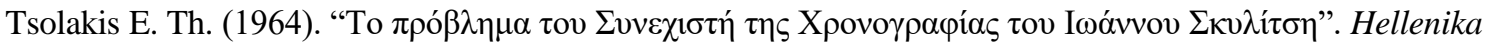
18 (1964) 79-83.

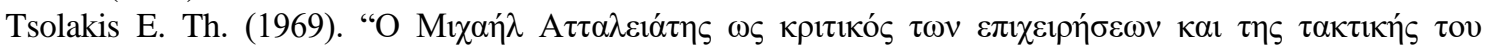

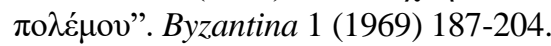

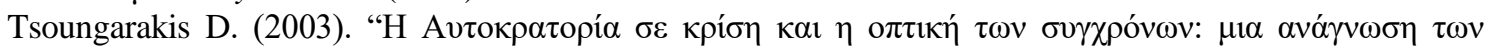

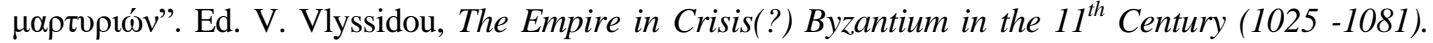
Athens (2003) 275-290.

Vratimos A. (2013). "Eudokia Makrembolitissa: Was she Implicated in the Removal of her Husband, Romanos IV Diogenes, from Power?”. Revue des études byzantines 71 (2013) 277-284.

Vryonis Sp. jr. (1971). The Decline of Medieval Hellenism in Asia Minor and the Process of Islamization from the Eleventh through the Fifteenth Century. Berkeley - Los Angeles - London 1971.

Vryonis Sp. Jr. (1992). “The Greek and Arabic Sources on the Battle of Mantzikert, 1071 A.D.”. Ed. Sp. Vryonis, Jr., Byzantine Studies, Essays on the Slavic World and the Eleventh Century. New York (1992) 125-140.

Vryonis Sp. jr. (2003). "The Eleventh Century: was there a Crisis in the Empire? The Decline of Quality and Quantity in the Byzantine Armed Forces". Ed. V. Vlyssidou, The Empire in Crisis(?) Byzantium in the $11^{\text {th }}$ Century (1025-1081) (2003) 17-43.

Zafeiris K. (2011). "The Issue of the Authorship of the Synopsis Chronike and Theodore Skoutariotes". Revue des études byzantines 69 (2011) 253-263. 
